\title{
Antioxidant and digestive enzyme inhibitory effects of Eisenia bicyclis extracted by different methods
}

\author{
Jin-Hak Kim, La Young Park, Shin-Ho Lee* \\ Department of Food Science and Technology, Catholic University of Daegu, Gyeongsan 38430, Korea
}

\section{추출방법에 따른 대황 추출물의 항산화 및 소화효소 저해 효과}

\author{
김진학 · 박나영 · 이신호* \\ 대구가톨릭대학교 식품가공학과
}

\begin{abstract}
The antioxidant and digestive enzyme inhibitory effects of Eisenia bicyclis extracted by various extraction methods (RE, reflux extraction; SE, ultrasonification extraction; AE, autoclave extraction; LE, low-temperature high-pressure extraction) were investigated. The extraction yield $(55.21 \%)$ and the laminarin $(39.03 \%)$, fucoidan $(24.75 \%)$, total polyphenol (115.68 mg GAE/g) and flavonoid (36.67 mg RHE/g) contents of AE were higher than those in other methods. The DPPH radical $(86.60 \%, 500 \mathrm{mg} \%)$, ABTS radical $(58.56 \%, 25 \mathrm{mg} \%)$, nitrite $(86.38 \%, 100 \mathrm{mg} \%)$ scavenging activities of the Eisenia bicyclis extracted by $\mathrm{AE}$ were higher than those of Eisenia bicyclis extracted by other methods. The ABTS radical and nitrite scavenging activities were above $98 \%$ in all tested Eisenia bicyclis extracts and these activities were dependent on its concentration. The inhibitory effects of $\mathrm{AE}$ against amylase (50 $\mathrm{mg} \%$ ) and a-glucosidase $(5 \mathrm{mg} \%$ ) were $64.76 \%$ and $86.71 \%$, respectively. The $\mathrm{AE}$ showed the best inhibitory effect of Eisenia bicyclis extracts (50 mg\%) against trypsin (24.37\%) and a-chymotrypsin (49.05\%), respectively. These results suggest that Eisenia bicyclis extracted by $\mathrm{AE}$ can be used as a bioactive and functional material in the food industry.
\end{abstract}

Key words : Eisenia bicyclis, antioxidant, digestive enzyme, extraction method

\section{서 론}

산업화 이후 계속적으로 증가하는 각종 환경오염물질, 흡연, 알코올 및 방사선 등은 인체에 산화적 스트레스를 가중시키며, 이러한 산화적 스트레스가 제거되지 못 하면 생체막의 손상, 고분자 단백질 및 DNA의 변형과 기능 상실 등으로 인한 동맥경화증, 암, 신경퇴행성 질환, 노화 등 여러 질병이 유발될 수 있으므로 산화적 스트레스를 해결하기 위한 항산화제에 대한 관심이 집중되고 있다(1). 또한, 현대 인들은 과잉의 영양섭취로 인한 비만(2)에 기인된 고지혈

*Corresponding author. E-mail : leesh@cu.ac.kr

Phone : 82-53-850-3217, Fax : 82-53-850-3217

Received 17 October 2015; Revised 24 November 2015; Accepted 9 December 2015.

Copyright (c) The Korean Society of Food Preservation. All rights reserved.
증, 당뇨병, 고혈압 등의 만성질환에 대한 우려가 확산되면 서 체중조절을 위한 식품의 필요성이 증대되고 있으나, 과 학적으로 증명된 식품이나 소재의 개발이 미흡한 상태이다 (3). 우리나라의 식단은 주로 곡류 즉, 탄수화물 위주로 구성 되어 있어 지방은 물론 탄수화물 및 단백질의 흡수 억제 활성까지 있어야 비만을 억제할 수 있는 식품 소재로 활용 가치가 있다.

해조류는 각종 미네랄과 비타민 및 섬유소, 단백질 등이 풍부하게 함유되어 있을 뿐만 아니라 고압, 저온, 저산소, 고염 등의 독특한 환경 속에서 서식하기 때문에 육상생물과 는 다른 대사계나 생체방어계를 가지고 있는 것으로 보고 (4)되어져 있으며, 항암(5), 항돌연변이(6), 항염증(7), 고지 혈증 및 고혈압 예방(8)과 멜라닌 생성 억제(7) 등 다양한 생리활성을 갖는 물질들을 함유하고 있다. 그 중 갈조류는 건물기준으로 탄수화물을 약 30 67\%까지 함유하고 있으 며, 갈조류가 함유하는 다당류는 대부분이 알긴산, 라미나 
린 및 후코이단 등으로 구성되어 있다(9). 대황(Eisenia bicyclis)은 다시마목(Laminariales) 미역과(Alariaceae)에 속 하는 다년생 식물로 주로 한국과 일본의 태평양 연안에서 널리 서식하고 있다. 대황은 다른 갈조류의 알긴산과 달리 함황당류인 laminarin을 함유하고 있으며, 이차 대사산물인 phlorotannin 유도체는 항산화(10), 항알러지(11), a -glucosidase 억제(12), 항콜레스테롤(13) 및 항바이러스(14) 등의 생리활성이 있는 것으로 알려져 새로운 기능성 소재로 서 부각되고 있다. 본 연구에서는 국내 연안에 자생하는 대황의 이용성 확대와 식품 소재로써 활용 가능성을 구명하 고자 추출 방법을 달리한 대황 추출물의 항산화 활성과 단백질 및 탄수화물 소화효소 저해 효과를 비교 검토하 였다.

\section{재료 및 방법}

재료 및 전처리

대황(Eisenia bicyclis)은 울릉도산을 사용하였으며, 흐르 는 물로 세척하여 염분을 제거한 뒤 건조하여 분쇄기(IKA® A11 basic, IKA ${ }^{\circledR}$ Werke GmbH \& Co., KG, Staufen, Germany)를 이용 40 mesh 이하로 분쇄한 후 $-20^{\circ} \mathrm{C}$ 에서 보관 하면서 실험에 사용하였다.

\section{추출방법}

대황의 추출은 분쇄시료 $100 \mathrm{~g}$ 에 20배의 증류수를 가한 후 환류냉각추출(reflux extraction)은 냉각관을 부착하여 8 $0^{\circ} \mathrm{C}$ 의 항온수조에서 3 시간 3 회 반복 추출하였고, 초음파추 출(ultrasonification extraction)은 시료를 넣은 유리병이 초 음파 수조(NXPC -4020P, KODO, Hwaseong, Korea) 바닥에 닿지 않도록 하여 $40 \mathrm{kHz}$ 로 2시간 3회 반복 추출하였다. 고온가압추출(autoclave extraction)은 autoclave(JSAC-100, JS Research Inc., Gongju, Korea)를 이용하여 $121^{\circ} \mathrm{C}$ 에서 15 분 동안 3 회 반복 추출하였다. 저온고압추출(low temperature high pressure extraction)은 저온고압추출기(FT110, benchtop rapid extractor, ARMFIELD, Ringwood, Hampshire, England)를 이용하여 실온에서 2시간 동안 $8.0 \mathrm{bar}$ 의 압력하 에서 3회 반복 추출하였다. 각각의 추출물은 여과지 (Whatman No. 2, Maidstone, England)로 여과한 후 회전진공 농축기(WB2000, Heidolph, Schwabach, Germany)로 농축한 후 동결 건조하여 사용하였다. 수율은 동결건조 시킨 건물 량을 원료 건물량에 대한 백분율로 나타내었다.

\section{조 라미나린 및 후코이단 함량}

상기 제조한 4종의 대황 추출물 시료 각각 $1 \mathrm{~g}$ 을 $50 \mathrm{~mL}$ 의 증류수에 녹이고, $\mathrm{CaCl}_{2}$ 를 $2 \%(\mathrm{w} / \mathrm{v})$ 가 되도록 첨가하여 상 온에서 12 시간 동안 반응시켜 조 라미나린(crude laminarin)
을 분리하였다. 반응 후 원심분리(Centrifuge 5810R, Eppendorf, Hamburg, Germany)하여 그 상등액에 3배(v/v) 의 에탄올을 첨가하여 침전물을 회수한 다음 acetone으로 수 회 처리한 후 건조하여 조 후코이단(crude fucoidan)을 얻었다. 각 추출물들의 조 알긴산 및 라미나란 함량은 분리 된 다당류를 건조시킨 건물 중량을 원료 건물량에 대한 백분율로 나타내었다(15).

\section{총 폴리페놀 및 플라보노이드 함량}

총 폴리페놀 함량 측정은 Folin-Denis 법(16)에 따라 시료 $1 \mathrm{~mL}$ 에 $0.2 \mathrm{~N}$ Folin-Ciocalteu's phenol reagent(SigmaAldrich Co., St. Louis, MO, USA) $1 \mathrm{~mL}$ 를 가하여 실온에서 3 분간 방치 후, $7.5 \% \mathrm{Na}_{2} \mathrm{CO}_{3} 1 \mathrm{~mL}$ 을 가하여 암소에서 1시 간 동안 반응 시킨후 후 $765 \mathrm{~nm}$ 에서 흡광도(Ultrospec 1000, Pharmacia Biotech Inc., Cambridge, UK)를 측정하였다. 총 폴리페놀 함량은 gallic acid를 표준물질로 한 표준곡선에 의하여 산출하였다.

플라보노이드 함량은 Abdel-Hameed의 방법(17)에 따라 시료 $1 \mathrm{~mL}$ 에 $5 \%$ sodium nitrite $0.15 \mathrm{~mL}$ 를 가한 후 $25^{\circ} \mathrm{C}$ 에서 6분간 방치한 다음 $10 \%$ aluminium chloride $0.3 \mathrm{~mL}$ 를 가하 여 $25^{\circ} \mathrm{C}$ 에서 5 분간 방치 후 $1 \mathrm{~N} \mathrm{NaOH} 1 \mathrm{~mL}$ 를 가하고 교반하여 $510 \mathrm{~nm}$ 에서 흡광도를 측정하였으며, rutin hydrate(Sigma-Aldrich Co.)의 검량선에 의하여 함량을 산출 하였다.

\section{DPPH radical 소거능}

$\mathrm{DPPH}$ radical 소거능의 측정은 Blois의 방법(18)을 변형 하여 시료 $0.4 \mathrm{~mL}$ 에 $0.4 \mathrm{mM} \mathrm{DPPH}(\mathrm{a}$, a-diphenyl- $\beta$ -picrylhydrazyl, Sigma-Aldrich Co.) 에탄올 용액 $0.8 \mathrm{~mL}$ 을 진탕 혼합하고, 10 분간 방치 후 $525 \mathrm{~nm}$ 에서 흡광도를 측정 하여 계산식, DPPH radical scavenging ability $(\%)=100-$ [(OD of sample/ OD of control $) \times 100]$ 에 의하여 활성을 산출 하였다.

\section{ABTS radical 소거능}

ABTS radical 소거능은 ABTS radical cation decolorization assay(19)를 이용하여 측정하였다. $7.4 \mathrm{mM}$ 의 ABTS[2,2'azino-bis(3-ethylbenzothiazoline-6-sulfonic acid) diammonium salt, Sigma-Aldrich Co.]와 $2.6 \mathrm{mM}$ potassium persulfate를 혼합하여 실온·암소에서 24시간 동안 radical을 형성시킨 다음 실험 직전에 $\mathrm{ABTS}$ 용액을 $732 \mathrm{~nm}$ 에서 흡광도가 $0.700 \pm 0.030$ (mean $\pm \mathrm{SD}$ )이 되도록 phosphate-buffered saline $(\mathrm{pH}$ 7.4)으로 희석하여 사용하였다. 추출물 $50 \mu \mathrm{L}$ 에 ABTS 용액 $950 \mu \mathrm{L}$ 를 첨가하여 암소에서 10 분간 반응시킨 후 732 $\mathrm{nm}$ 에서 흡광도를 측정하여 계산식, $\mathrm{ABTS}$ radical scavenging ability $(\%)=100-[(\mathrm{OD}$ of sample/ OD of control $) \times 100]$ 에 의하 여 활성을 산출하였다. 
아질산염소거능

아질산염 소거능은 Kato 등(20)의 방법에 따라 각 추출물 $1 \mathrm{~mL}$ 에 $1 \mathrm{mM}$ sodium nitrite $1 \mathrm{~mL}$ 를 가하고 $0.1 \mathrm{~N}$ hydrogen chloride를 가하여 총 부피를 $10 \mathrm{~mL}$ 로 하였다. 이 용액을 $37^{\circ} \mathrm{C}$ 에서 1 시간 반응시킨 후 $1 \mathrm{~mL}$ 를 취하여 $2 \%$ acetic acid $4 \mathrm{~mL}$ 와 30\% acetic acid로 용해한 Griess reagent $(1 \%$ sulfanilic acid : $1 \%$ naphthylamine $=1: 1) 0.4 \mathrm{~mL}$ 를 가하고 실온에서 15 분간 방치한 후 $520 \mathrm{~nm}$ 에서 흡광도를 측정하여 계산식, nitrite scavenging ability $(\%)=100-[(\mathrm{OD}$ of sample/ $\mathrm{OD}$ of control) $\times 100$ ]에 의하여 산출하였다.

\section{a-Amylase 저해효과}

a-Amylase 저해효과는 $\operatorname{Lim}$ 등의 방법(21)을 변형하여 측정하였다. 시료 $20 \mu \mathrm{L}$ 에 $1 \mathrm{unit} / \mathrm{mL}$ porcine pancreas 기원 의 a-amylase $5 \mu \mathrm{L}$ 와 $50 \mathrm{mM}$ potassium phosphate buffer $(\mathrm{pH}$ 6.9) $25 \mu \mathrm{L}$ 를 혼합하여 $37^{\circ} \mathrm{C}$ 에서 20 분간 전 처리한 후 $0.5 \%$ $\operatorname{starch}$ 를 $25 \mu \mathrm{L}$ 첨가하여 $37^{\circ} \mathrm{C}$ 에서 20 분간 반응시켰다. 그 반응액에 $48 \mathrm{mM}$ 3,5-dinitrosalicylic acid(DNS) 발색시약을 $100 \mu \mathrm{L}$ 넣고 $100^{\circ} \mathrm{C}$ 에서 10 분간 끓여 발색시킨 후 충분히 냉각시킨다. 이 반응액에 $1 \mathrm{~mL}$ 물을 가하고 잘 교반한 후 $540 \mathrm{~nm}$ 에서 흡광도를 측정하였다. a-Amylase 저해효과(\%) 는 [1-( $\left.\left(\mathrm{C}_{\mathrm{Abs}}-\mathrm{S}_{\mathrm{Abs}}\right) /\left(\mathrm{C}_{\mathrm{Abs}}-\mathrm{B}_{\mathrm{Abs}}\right)\right] \times 100: \mathrm{C}_{\mathrm{Abs}}$, 대조구 흡광도; $\mathrm{S}_{\mathrm{Abs}}$, 시료 흡광도; $\mathrm{B}_{\mathrm{Abs}}$, 시료 무첨가구의 흡광도에 의하여 산출 하였다.

\section{a-Glucosidase 저해효과}

$\mathrm{Kim}$ 등의 방법(22)에 따라 추출물 $0.05 \mathrm{~mL}, 0.2 \mathrm{unit} / \mathrm{mL}$ a-glucosidase $0.05 \mathrm{~mL}$ 와 $200 \mathrm{mM}$ potassium phosphate buffer(pH 7.0) $0.05 \mathrm{~mL}$ 를 혼합하여 $37^{\circ} \mathrm{C}$ 에서 10 분간 전처리 한 다음 $3 \mathrm{mM} \rho \mathrm{NPG}(\rho$-nitrophenyl a-D-glucopyranoside) 0.1 $\mathrm{mL}$ 를 가하여 $37^{\circ} \mathrm{C}$ 에서 10 분간 반응시킨 후 $0.1 \mathrm{M}$ sodium carbonate $0.75 \mathrm{~mL}$ 로 반응을 정지시켜 $405 \mathrm{~nm}$ 에서 흡광도

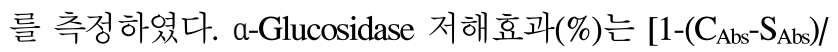
$\left.\left(\mathrm{C}_{\mathrm{Abs}}-\mathrm{B}_{\mathrm{Abs}}\right)\right] \times 100: \mathrm{C}_{\mathrm{Abs}}$, 대조구 흡광도; $\mathrm{S}_{\mathrm{Abs}}$, 시료 흡광도; $\mathrm{B}_{\mathrm{Abs}}$, 시료 무첨가구의 흡광도에 의하여 산출하였다.
Trypsin 및 $a^{-c h y m o t r y p s i n ~ ㅈ ㅓ ㅎ ㅐ ㅎ ㅛ ㄱ ㅘ ~}$

Trypsin 및 a-chymotrypsin 저해효과는 Jang 등의 방법 (23)에 따라 $10 \mathrm{mM}$ sodium acetate buffer(pH 7.5)에 $0.01 \%$ trypsin 및 a-chymotrypsin을 용해하여 효소액으로 사용하였 다. Trypsin 및 a-chymotrypsin 효소액 $0.015 \mathrm{~mL}$ 에 시료 $0.185 \mathrm{~mL}$ 을 혼합하여 $37^{\circ} \mathrm{C}$ 에서 10 분간 전 처리 후 $10 \mathrm{mM}$ potassium phosphate buffer(pH 7.5)에 용해한 3\% azocasein $0.8 \mathrm{~mL}$ 을 첨가하여 $37^{\circ} \mathrm{C}$ 에서 30 분간 반응시킨 뒤 $110 \mathrm{mM}$ trichloroacetic acid(TCA) $1.0 \mathrm{~mL}$ 을 첨가하여 반응을 정지시 켰다. 상온에서 15 분간 반응액을 정치하여 단백질을 침전 시키고 $10,000 \times \mathrm{g}$ 에서 20 분간 원심분리(Wisespin CF- 10 , Daihan Scientific Co., Wonju, Korea)한 뒤 상등액 $1.2 \mathrm{~mL}$ 에 $1 \mathrm{~N} \mathrm{NaOH} 1.4 \mathrm{~mL}$ 을 혼합하여 $440 \mathrm{~nm}$ 에서 흡광도를 측정하 였다. Trypsin 및 a-chymotrypsin 저해효과(\%)는 [1-( $\mathrm{C}_{\mathrm{Abs}}{ }^{-}$ $\left.\left.\mathrm{S}_{\mathrm{Abs}}\right) /\left(\mathrm{C}_{\mathrm{Abs}}-\mathrm{B}_{\mathrm{Abs}}\right)\right] \times 100: \mathrm{C}_{\mathrm{Abs}}$, 대조구 흡광도; $\mathrm{S}_{\mathrm{Abs}}$, 시료 흡광 도; $\mathrm{B}_{\mathrm{Abs}}$, 시료 무첨가구의 흡광도에 의하여 산출하였다.

\section{통계분석}

실험결과의 유의성 검증은 SPSS(Statistical Package for Social Sciences, version 19.0, IBM SPSS Inc., Chicago, IL, USA) software package를 이용하여 분산분석(ANOVA)을 하였으며 각 처리구간 유의성은 Duncan's multiple range test에 의하여 검증하였다.

\section{결과 및 고찰}

추출 수율, 라미나린, 후코이단, 폴리페놀 및 플라보노이드 함량

Table 1에서 보는 바와 같이 추출방법을 달리한 대황 열수추출물의 수율, 라미나린, 후코이단, 폴리페놀 및 플라 보노이드 함량은 추출방법에 따라 유의적인 차이를 나타내 었다(p<0.05). 환류냉각추출물 $(\mathrm{RE})$, 초음파추출물(SE), 고 온가압추출물(AE), 저온고압추출물(LE)의 수율과 주요 성 분 함량은 $\mathrm{AE}, \mathrm{RE}, \mathrm{SE}, \mathrm{LE}$ 순으로 높았다. 그중 고온가압추

Table 1. Comparison of yield and, laminarin, fucoidan, total polyphenol and flavonoid contents of Eisenia bicyclis extracted by different extraction methods

\begin{tabular}{cccccc}
\hline Method $^{1)}$ & Yield (\%) & Laminarin (\%) & Fucoidan (\%) & $\begin{array}{c}\text { Polyphenol } \\
\left(\mathrm{mg} \mathrm{GAE}^{2} / \mathrm{g}\right)\end{array}$ & $\begin{array}{c}\text { Flavonoid } \\
\left(\mathrm{mg} \mathrm{RHE}^{3} / \mathrm{g}\right)\end{array}$ \\
\hline $\mathrm{RE}$ & $51.61 \pm 0.26^{\mathrm{c} 4)}$ & $36.95 \pm 0.73^{\mathrm{c}}$ & $22.50 \pm 0.69^{\mathrm{c}}$ & $109.07 \pm 3.67^{\mathrm{c}}$ & $34.47 \pm 0.54^{\mathrm{c}}$ \\
$\mathrm{SE}$ & $38.97 \pm 0.28^{\mathrm{b}}$ & $28.08 \pm 1.09^{\mathrm{b}}$ & $21.25 \pm 0.59^{\mathrm{b}}$ & $94.70 \pm 1.98^{\mathrm{b}}$ & $32.79 \pm 0.88^{\mathrm{b}}$ \\
$\mathrm{AE}$ & $55.21 \pm 0.27^{\mathrm{d}}$ & $39.03 \pm 0.53^{\mathrm{d}}$ & $24.75 \pm 0.44^{\mathrm{d}}$ & $115.68 \pm 3.72^{\mathrm{d}}$ & $36.67 \pm 1.75^{\mathrm{d}}$ \\
$\mathrm{LE}$ & $19.22 \pm 0.22^{\mathrm{a}}$ & $17.75 \pm 0.40^{\mathrm{a}}$ & $17.92 \pm 0.55^{\mathrm{a}}$ & $80.19 \pm 2.13^{\mathrm{a}}$ & $31.15 \pm 1.50^{\mathrm{a}}$ \\
\hline
\end{tabular}

\footnotetext{
${ }^{1)} \mathrm{RE}$, reflex extraction; SE, ultrasonification extraction; $\mathrm{AE}$, autoclave extraction; LE, low-temperature high-pressure extraction.

${ }^{2)} \mathrm{GAE}$, gallic acid equivalents.

${ }^{3} \mathrm{RHE}$, rutin hydrate equivalents.

${ }^{4}$ Means with different superscripts within a column indicate significant differences $(\mathrm{p}<0.05)$.
} 
출물(AE)의 수율, 라미나린, 후코이단, 폴리페놀, 플라보노 이드 함량이 각각 $55.21 \%, 39.03 \%, 24.75 \%, 115.68 \mathrm{mg}$ $\mathrm{GAE} / \mathrm{g}, 36.67 \mathrm{mg} \mathrm{RHE} / \mathrm{g}$ 으로 추출물 중 가장 높았다. $\mathrm{AE}$ 와 $\mathrm{RE}$ 가 높은 수율을 나타내는 것은 열처리 공정에 의하여 불용성 세포벽의 수용화에 의해 수용성 식이섬유가 증가하 게 되고, 수용화 과정 중에 불용성 식물세포벽으로부터 식 이섬유 성분이 용해되며, 또한 고압 하에서는 단백질이 변 성되거나 세포막이 비가역적으로 분해되어 막 투과성이 증가(24)됨에 따라 물질 이동이 용이하게 되어 보다 많은 성분이 세포 밖으로 용출된 것이라 판단된다. 추출물에 함 유된 라미나린과 후코이단은 해조류에 존재하는 주요 기능 성 다당류로 항암활성, 면역증강 효과(25)가 있어 기능성 식품소재로서의 활용이 가능할 것으로 판단된다.

\section{DPPH 및 ABTS radical 소거능}

추출방법을 달리하여 제조한 대황 추출물의 $\mathrm{DPPH}$ radical 소거능 측정 결과는 Fig. 1 과 같이 모든 시료에서 농도 의존적으로 증가하였으며, $500 \mathrm{mg} \%$ 농도에서 $\mathrm{AE}(86.60 \%), \mathrm{RE}(84.41 \%), \mathrm{SE}(83.09 \%), \mathrm{LE}(80.45 \%)$ 순으로 총 폴리페놀 및 플라보노이드 함량(table 1)이 높은 $\mathrm{AE}$ 에서 가장 우수한 DPPH radical 소거능을 나타내었다. 대황 추출 물의 ABTS radical 소거능(Fig. 2)은 DPPH radical 소거능과 동일하게 모든 시료에서 농도 의존적으로 증가하였고 50 $\mathrm{mg} \%$ 농도에서 모두 $98 \%$ 이상의 높은 활성을 나타내었으 며, $\mathrm{AE}, \mathrm{RE}, \mathrm{SE}, \mathrm{LE}$ 순으로 높았다. 항산화 물질은 심혈관 질환, 동맥 경화증, 관상 동맥 심장질환, 인슐린 저항성을 포함한 많은 질병 프로세스에 관여하는 활성산소종(reactive oxygen species)을 감소하여 건강을 유지하도록 도와준다 (26). Butylated hydroxytoluene(BHT) 및 butylated hydroxyanisole(BHA)는 강력한 합성 항산화제로 알려졌지만, 동물 에 대한 독성 및 발암을 일으키는 것으로 보고되고 있다 (27). 따라서 천연 항산화 물질을 찾아내는 것이 무엇보다

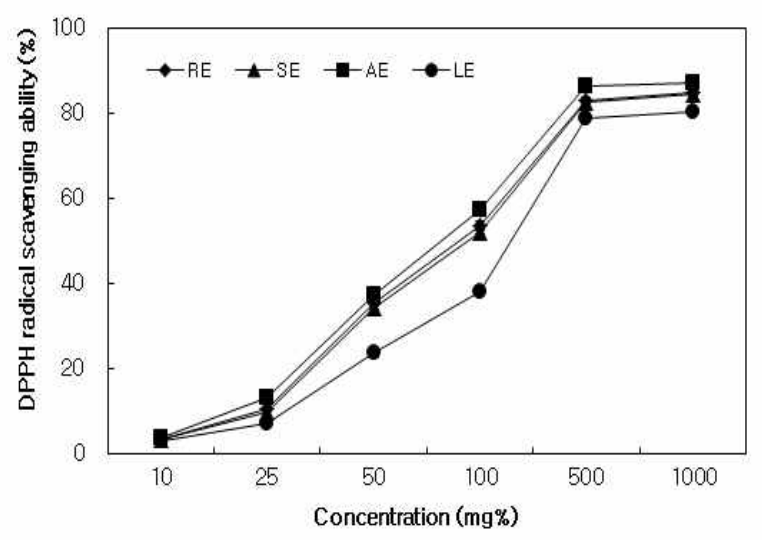

Fig. 1. Comparison of DPPH radical scavenging activities of Eisenia bicyclis extracted using different extraction methods.

$\mathrm{RE}$, reflex extraction; $\mathrm{SE}$, ultrasonification extraction; $\mathrm{AE}$, autoclave extraction; $\mathrm{LE}$, low-temperature high-pressure extraction.

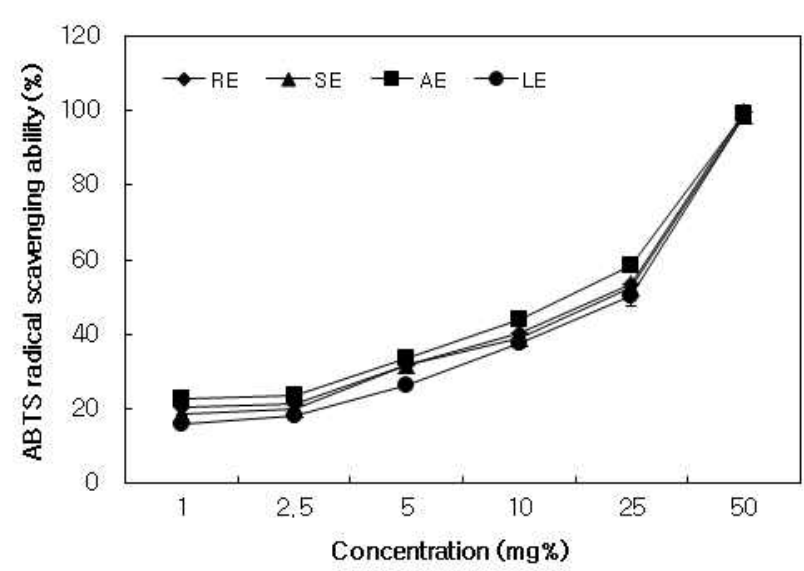

Fig. 2. Comparison of ABTS radical scavenging activities of Eisenia bicyclis extracted using different extraction methods.

$\mathrm{RE}$, reflex extraction; SE, ultrasonification extraction; $\mathrm{AE}$, autoclave extraction; $\mathrm{LE}$, low-temperature high-pressure extraction.

중요하게 인식되고 있으며, 대황 추출물은 항산화 활성이 우수한 천연소재로서 활용이 가능할 것으로 판단된다.

\section{아질산염 소거능}

추출방법에 다른 대황 추출물의 아질산염 소거능의 변화 는 Fig. 3과 같다. 대황 추출물의 아질산염 소거능은 모든 실험군에서 농도 의존적으로 증가하였고 $\mathrm{AE}, \mathrm{RE}, \mathrm{SE}, \mathrm{LE}$ 순으로 높았으며, $500 \mathrm{mg} \%$ 농도에서 모두 $98 \%$ 이상의 높은 활성을 나타내었다. 발암성 물질인 N-nitroso화합물의 전구체의 하나인 아질산염은 미량이기는 하나 야채, 곡류 를 비롯한 각종 농산물에 널리 함유되어 있고, 육제품이나 기타 식품의 보존과 발색 안정을 위해 식품 첨가물로도 사용되고 있다. 특히 아질산염은 그 자체가 지니는 독성 때문에 일정농도 이상 섭취하게 되면 각종 중독 증상을 일으키며(28), polyphenol과 flavonoid 화합물은 종류에 따

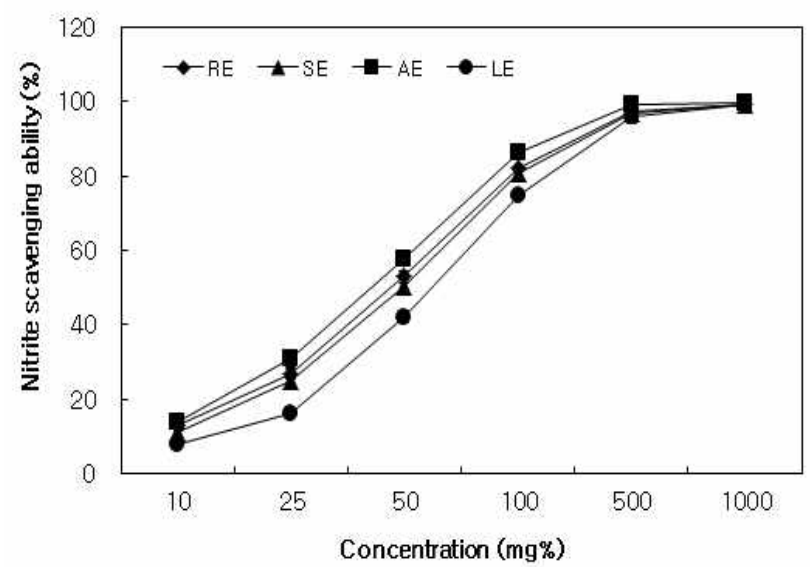

Fig. 3. Comparison of nitrite radical scavenging activities of Eisenia bicyclis extracted using different extraction methods.

$\mathrm{RE}$, reflex extraction; SE, ultrasonification extraction; $\mathrm{AE}$, autoclave extraction; $\mathrm{LE}$, low-temperature high-pressure extraction. 
라 차이는 있으나 아질산염을 효과적으로 분해하여 nitrosamine의 생성을 억제한다고 보고되었다(29). 그러므 로 대황 추출물을 식품첨가물로 사용할 경우 아질산염에 기인된 가공과정 중 nitrosamine 생성을 억제할 수 있을 것으로 판단된다.

\section{탄수화물 분해효소 저해효과}

a-Amylase는 녹말(amylose 및 amylopectin)이나 glycogen 과 같은 다당류에 작용하여 포도당과 엿당으로 분해하는 소화효소이다. 또한 a-glucosidase는 a-amylase에 의해 분해 된 당질 중 엿당을 단당류인 포도당으로 전환시키는 소화효 소이다. 이러한 효소의 활성 저해는 당질 가수분해와 흡수 과정을 지연시킴으로 식후 당 농도를 제한한다(30). 추출방 법을 달리한 대황 추출물의 탄수화물 분해효소 저해 효과를 측정한 결과는 Fig. 4와 같다. 탄수화물 소화효소 중 amylase 저해 효과는 $50 \mathrm{mg} \%$ 농도에서 $\mathrm{AE}(64.76 \%), \mathrm{RE}(58.57 \%)$, $\mathrm{SE}(54.76 \%), \mathrm{LE}(45.48 \%)$ 순으로 나타났으며, a-glucosidase 저해효과는 $5 \mathrm{mg} \%$ 농도에서 $\mathrm{AE}(86.71 \%), \mathrm{RE}(81.87 \%)$, $\mathrm{SE}(75.21 \%), \mathrm{LE}(72.65 \%)$ 순으로 나타났다. 이러한 결과는 $121{ }^{\circ} \mathrm{C}$ 에서 15 분간 고온가압 추출법을 이용한 대황 열수 추출물 $(\mathrm{AE})$ 이 가장 우수한 탄수화물 소화효소 저해효과를 나타내었다. 체내에서 과량의 당질은 지방으로 전환되어 체중증가를 유발하므로 대황 추출물을 이용하여 탄수화물 분해효소의 활성을 억제할 경우 비만을 예방 할 수 있을것
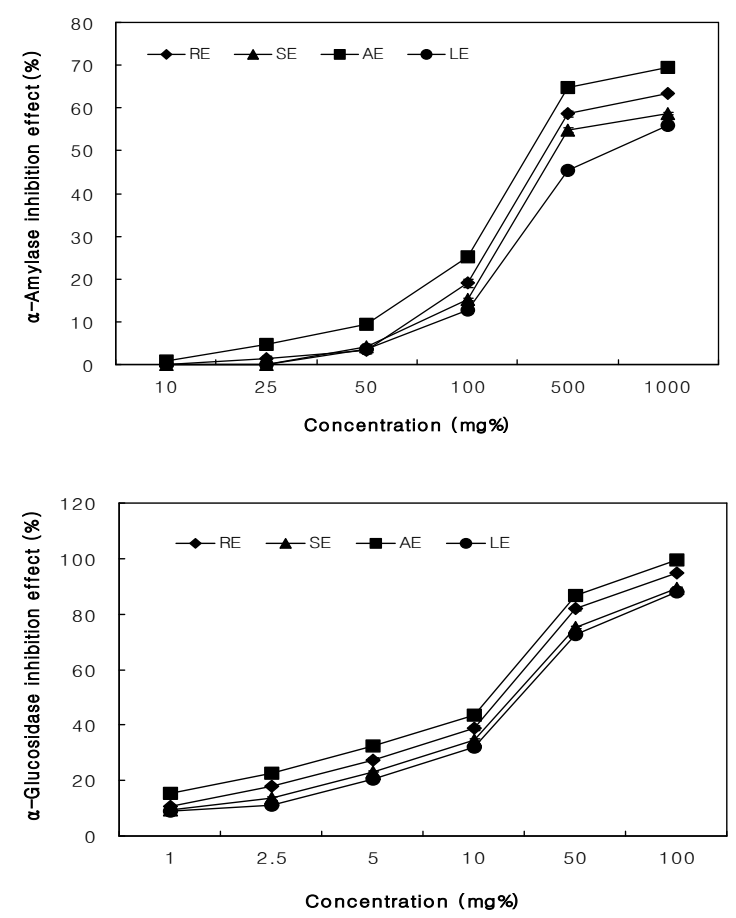

Fig. 4. Comparison of a-amylase and a-glucosidase inhibition effects of Eisenia bicyclis extracted using different extraction methods.

$\mathrm{RE}$, reflex extraction; SE, ultrasonification extraction; $\mathrm{AE}$, autoclave extraction; LE, low-temperature high-pressure extraction.
으로 판단된다. 특히 a-glucosidase는 식후 혈당치 증가에 밀접한 관계가 있으므로 이를 저해한다는 것은 혈당조절식 품개발의 소재로 활용이 가능할 것으로 판단된다.

\section{단백질 분해 효소 저해 효과}

단백질분해에 관여하는 효소인 trypsin은 췌장에서 trypsinogen 형태로 만들어져 소장에 운반되어 enterokinase 또는 trypsin 자체에 의해 활성화되어 단백질을 분해하게 된다. a-Chymotrypsin은 역시 췌장에서 활성이 없는 전구물 질인 chymotrypsinogen의 형태로 소장에 분비되고, trypsin 이나 chymotrypsin 자체에 의하여 활성화되어 단백질을 분 해한다(31). 대황 추출물의 단백질 분해 효소 중 trypsin 저해 효과(Fig. 5)는 $50 \mathrm{mg} \%$ 농도에서 $\mathrm{AE}(24.37 \%)$, $\mathrm{RE}(22.76 \%), \mathrm{SE}(19.97 \%), \mathrm{LE}(15.95 \%)$ 순으로 나타났으며, a-chymotrypsin 저해효과는 $50 \mathrm{mg} \%$ 농도에서 $\mathrm{AE}(49.05 \%)$, $\mathrm{RE}(43.60 \%), \mathrm{SE}(40.63 \%), \mathrm{LE}(38.10 \%)$ 순으로 나타내어 대 황 추출물은 단백질 분해효소 저해효과가 있음을 알 수 있으며, 이러한 효과를 나타냄으로써 체내에서 분해되는 단백질의 양을 감소시켜 단백질의 과잉 흡수를 방지하여 체중조절 및 비만 예방에 효과 있을 것으로 판단된다.

이상의 결과 대황 추출물은 해조류 유래의 기능성 다당 류인 라미나린과 후코이단이 풍부하고, 식물체의 주요 생 리활성 성분인 폴리페놀 및 플라보노이드를 충분히 함유하 고 있어 항산화활성이 우수할 뿐 아니라 탄수화물, 단백질
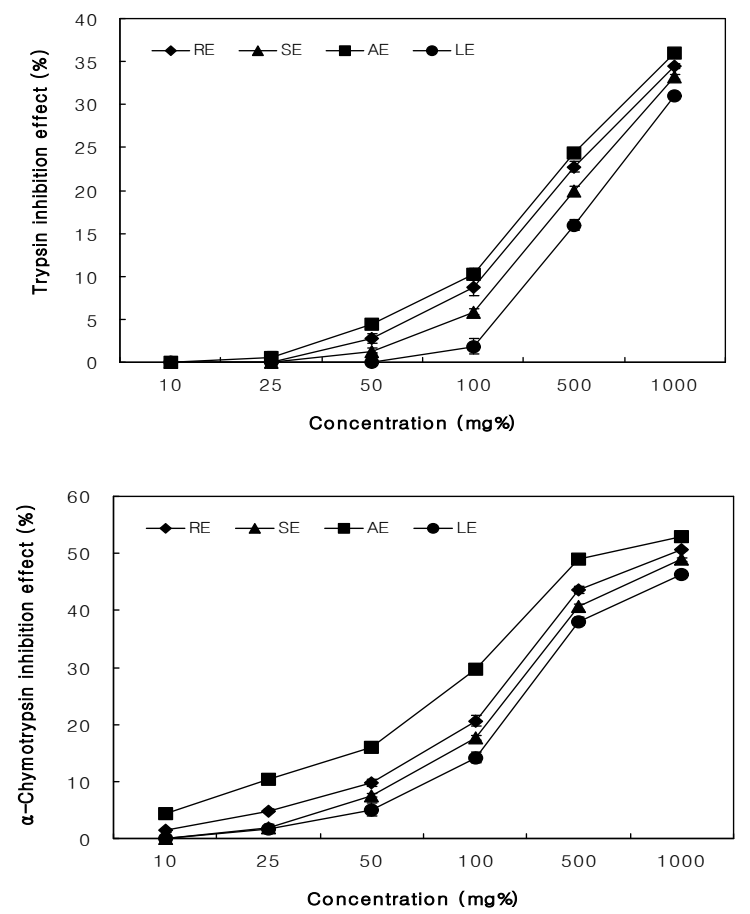

Fig. 5. Comparison of trypsin and a-chymotrypsin inhibition effects of Eisenia bicyclis extracted using different extraction methods.

$\mathrm{RE}$, reflex extraction; SE, ultrasonification extraction; $\mathrm{AE}$, autoclave extraction; $\mathrm{LE}$, low-temperature high-pressure extraction. 
소화효소 저해효과가 있어, 대황 추출물을 이용한 항당뇨, 항비만 효과가 있는 식품 개발을 유도할 수 있는 소재로서 의 활용이 가능할 것으로 판단되며, 대황 추출방법은 $121^{\circ} \mathrm{C}$ 에서 15 분간 열처리하는 고온가압 추출방법이 가장 효과적 인 것으로 판단된다. 아울러 이러한 생리활성을 가진 소재 로서의 활용에 앞서 동물실험이나 간이 임상실험을 통해 실제 체내에서 항산화, 항비만, 항당뇨 효과를 확인하는 보다 광범위한 연구가 필요할 것으로 판단된다.

\section{요 약}

미역과에 속하는 대황 물 추출물의 항산화활성과 탄수화 물 및 단백질 소화효소 저해능을 추출방법을 달리하여 비교 검토하였다. 환류냉각추출물(RE), 초음파추출물(SE), 고온 가압추출물 $(\mathrm{AE})$, 저온고압추출물(LE)의 수율과 주요 성분 함량은 $\mathrm{AE}, \mathrm{RE}, \mathrm{SE}, \mathrm{LE}$ 순으로 높았다. 고온가압추출물 (AE)의 수율, 라미나린, 후코이단, 폴리페놀, 플라보노이드 함량은 각각 $55.21 \%, 39.03 \%, 24.75 \%, 115.68 \mathrm{mg} \mathrm{GAE} / \mathrm{g}$, $36.67 \mathrm{mg} \mathrm{RHE} / \mathrm{g}$ 을 나타내었다. DPPH radical 소거능 모든 시료에서 농도 의존적으로 증가하였으며, $500 \mathrm{mg} \%$ 농도에 서 $\mathrm{AE}(86.60 \%), \mathrm{RE}(83.09 \%), \mathrm{SE}(84.41 \%), \mathrm{LE}(80.45 \%)$ 순이 었다. ABTS radical 소거능은 $50 \mathrm{mg} \%$ 농도에서 모두 98\% 이상의 높은 활성을 나타내었다. 아질산염 소거능은 모든 실험군에서 농도 의존적으로 증가하였고 $\mathrm{AE}, \mathrm{RE}, \mathrm{SE}, \mathrm{LE}$ 순으로 높았으며, $500 \mathrm{mg} \%$ 농도에서 추출방법에 관계없이 $98 \%$ 이상의 높은 활성을 나타내었다. 탄수화물 소화효소 중 amylase 저해 효과는 $50 \mathrm{mg} \%$ 농도에서 $\mathrm{AE}(64.76 \%)$, $\mathrm{RE}(58.57 \%), \mathrm{SE}(54.76 \%), \mathrm{LE}(45.48 \%)$ 순으로 나타났으며, a-glucosidase 저해효과는 $5 \mathrm{mg} \%$ 농도에서 $\mathrm{AE}(86.71 \%)$, $\mathrm{RE}(81.87 \%), \mathrm{SE}(75.21 \%), \mathrm{LE}(72.65 \%)$ 순으로 나타났다. 단 백질 분해 효소 중 trypsin 저해 효과는 $50 \mathrm{mg} \%$ 농도에서 $\mathrm{AE}(24.37 \%), \operatorname{RE}(22.76 \%), \mathrm{SE}(19.97 \%), \mathrm{LE}(15.95 \%)$ 순으로 나타났으며, a-Chymotrypsin 저해효과는 $50 \mathrm{mg} \%$ 농도에서 $\mathrm{AE}(49.05 \%), \mathrm{RE}(43.60 \%), \mathrm{SE}(40.63 \%), \mathrm{LE}(38.10 \%)$ 순이었 으며, 대황 추출방법은 $121^{\circ} \mathrm{C}$ 에서 15 분간 열처리하는 고온 가압 추출방법이 가장 양호하였다.

\section{References}

1. Thannickal VJ, Fanburg BL (2000) Reactive oxygen species in cell signaling. Am J Physiol Lung Cell Mol Physiol, 279, 1005-1029

2. Shin JH (2006) A study on the extraction and properties of pancreatic lipase inhibitor from Cassia tora Linne. MS Thesis, University of Seoul, Seoul, Korea, p 1-61
3. Kim JH, Son IS, Kim JS, Kim KH, Kwon CS (2006) Lipase-inhibitory and anti-oxidative activity of the methanol extract and the powder of Phellinus linteus. J Korean Soc Food Sci Nutr, 37, 154-161

4. Konig GM, Wright AD, Sticher O, Angerhofer CK, Pezzuto JM (1994) Biological activities of selected marine natural products. Planta Med, 60, 532-537

5. Kong CS, Um YR, Lee JI, Kim YA, Lee JS, Seo YW (2008) Inhibition effects of extracts and its solvent fractions isolated from Limonium tetragonum on growth of human cancer cells. Korean J Biotechnol Bioeng, 23, 177-182

6. Kim SA, Kim J, Woo MK, Kwak CS, Lee MS (2005) Antimutagenic and cytotoxic effects of ethanol extracts from five kinds of seaweeds. J Korean Soc Food Sci Nutr, 34, 451-459

7. Kang MC, Lee YJ, Ko RK, Kim HB, Hong SH, Kim GO (2008) Melanin inhibitory effects and anti-inflammatory effects of Dietyota coriacea extracts derived from adjacent sea of the Jeju island. Korean J Biotechnol Bioeng, 23, 311-316

8. Cahyana AH, Shuto Y, Kinoshita Y (1992) Pyropheophytina as an antioxidative substance from the marine alga, Arame (Eisenia bicyclis). Biosci Biotech Biochem, 56, 1533-1535

9. Koo JG (1997) Structural characterization of purified fucoidan from Laminaria religiosa, sporophylls of Undaria pinnatifiada, Hizikia pinnatifida and Sagassum fulvellum in Korea. J Korean Fish Soc, 30, 128-131

10. Lee HO, Kim DS, Do JR, Ko YS (1999) Angiotensin-I converting enzyme inhibitory activity of algae. J Korean Fish Soc, 32, 427-431

11. Sugiura Y, Matsuda K, Yamada Y, Nishikawa M, Shioya K, Katsuzaki H, lmai K, Amano H (2006) Isolation of a new anti-allergic phlorotannin, phlorofucofuroeckol-B, from and edible brown alge, Eisenia arborea. Biosci Biotech Biochem, 70, 2807-2811

12. Moon HE, Amano MN, Ahn BR, Chowdhury SS, Sohn HS, Jung HA, Choi JS (2011) Protein tyrosine phosphatase 1B and a-glucosidase inhibitory phlorotannins from edible brown algae, Ecklonia stolonifera and Eisenia bicyclis. Biosci Biotech Biochem, 75, 1472-1480

13. Kim YM, Han CK, Bang SJ, Park JH (2006) Effect of laminaran from Eisenia bicyclis on serum lipids in rats fed high cholesterol diet. J Korean Soc Food Sci Nutr, 36, 841-846

14. Witvrouw M, De Clercq E (1997) Sulfated polysaccharides 
extracted from sea algae as potential antiviral drugs. Gen Pharmacol, 29, 497-511

15. Kim YM, Do JR, Kim DS, Park JH (2006) Cytotoxicities of hydrolyzed crude laminaran from Eisenia bicyclis on the SNU-1, HeLa and SW cells. Korean J Food Sci Technol, 38, 793-798

16. Folin O, Denis W (1912) On phosphotungsticphosphomolybdic compounds as color reagents. J Biol Chem, 12, 239-249

17. Abdel-Hameed ESS (2008) Total phenolic contents and free radical scavenging activity of certain Egyptian Ficus species leaf samples. Food Chem, 114, 1271-1277

18. Blois MS. (1958) Antioxidant determination by the use of a stable free radical. Nature, 181, 1199-1200

19. Re R, Pellegrini N, Proteggente A, Pannala A, Yang M, Rice-Evans C (1999) Antioxidant activity applying an improved ABTS radial cation decolorization assay. Free Radic Biol Med, 26, 1231-1237

20. Kato H, Lee IE, Chuten NV, Kim SB, Hayase F (1987) Inhibition of nitrosamine formation by nondialyzable melanoidins. Agric Biol Chem, 51, 1333-1338

21. Lim CS, Li CY, Kim YM, Lee WY, Rhee HI (2005) The inhibitory effect of Cornus walteri extract against a-amylase. J Korea Soc Appl Biol Chem, 48, 103-108

22. Kim KY, Nam KA, Kurihara H, Kim SM (2008) Potent a-glucosidase inhibitors purified from the red alga Grateloupia elliptica. Phytochemistry, 69, 2820-2825

23. Jang YS, Jeong JM (2010) Antioxidative effect and digestive enzyme inhibition of grape seed extract (GSE).
J Korean Soc Food Sci Nutr, 39, 783-788

24. Hwang JK, Kim CT, Hong SI, Kim CJ (1994) Solubilization of plant cell walls by extrusion. J Korean Soc Food Nutr, 23, 358-370

25. Choi Y, Lee SM, Chun J, Lee HB, Lee J (2006) Influence of heat treatment on the antioxidant activities and polyphenolic compounds of Shiitake (Lentinus edodes) mushroom. Food Chem, 99, 381-387

26. Kaur C, Kapoor HC (2002) Antioxidant activity and total phenolic content of some asian vegetables. Int J Food Sci Technol, 37, 153-161

27. Teissedre PL, Frankel EN, Waterhouse AL, Peleg H, German JB (1996) Inhibition of in vitro human LDL oxidation by phenolic antioxidants from grapes and wines. J Sci Food Agric, 70, 55-61

28. Yamada T, Yamamoto M, Tamura A (1978) Studies on the formation of nitrosamines VII; The effects of some polyphenols on nitrosation of diethylamine. J Food Hyg Soc Japan, 19, 224-229

29. Swann PF (1975) The toxicology of nitrite, nitrate, and N-nitroso compounds. J Sci Food Agric, 26, 1761-1764

30. Mai TT, Thu NN, Tien PG, Chuyen NV (2007) Alpha-glucosidase inhibitory and antioxidant activities of Vietnamese edible plants and their relationships with polyphenol contents. J Nutr Sci Vitaminol, 53, 267-276

31. Kim JB (1998) Purification and properties of protease inhibitor from Streptomyces sp. SK-862. Korean J Food Nutr, 11, 678-682 